\title{
ED151, A Flawed Approach
}

\author{
Professor Brian Andrew, \\ Charles Darwin University \\ Mark Hughes, \\ University of Canberra
}

\begin{abstract}
This paper argues the recent proposals expressed by the Australian Accounting Standard Board in Exposure Draft 151 contradicts the historical trend of standard setters attempting to achieve the objective of financial reporting, that is, the provision of decision-useful information for users of general purpose financial reports. Historically, standard setters have tried to achieve this objective by reducing alternative treatments in accounting standards and providing increasing levels of information for users. Exposure Draft 151 affects many standards, however, this paper focuses on the proposal to allow preparers the option of selecting between the direct or indirect method of presenting cash flows from operations in the statement of cash flows. We argue that this discretion contradicts the stated objective of financial reporting, as stated in the Conceptual Framework, as it will lead to the widespread adoption of the less informative indirect method, due to a structural bias in the requirements of AASB 107 and IASB 7, the relevant standards relating to the statement of cash flows.
\end{abstract}

Key words: Exposure Draft 151; Australian Accounting Standards; Conceptual Framework; Cash Flows; Discretion; Direct method; Indirect method.

\section{INTRODUCTION}

In November 2006 the AASB published ED 151, entitled Australian Additions to, and Deletions from, IFRSs, in which it is broadly proposed to remove almost all current differences between Australian Accounting Standards Board (AASB) standards and relevant International Accounting Standards Board (IASB) standards (IFRS and IAS). It is argued here that the AASB has adopted the wrong approach because of the negative impact that this move will have upon the overall quality of AASB standards and the dubious benefits claimed for this dramatic surrender of Australian sovereignty to a private club dominated by overseas interests. In this paper, an accounting treatment for a given transaction is rated as being of higher quality than an alternative treatment if the former provides more useful information to users and this information can be expected to improve the decision-making abilities of these users, compared to the information provided by the alternative treatment. In such a case the decision-usefulness objective of the Conceptual Framework will not have been met, or at least there will have been a diminution in the decision-usefulness of the information required by the standard if the alternative treatment is adopted.

ED 151 lists a range of areas where there are differences between AASB standards and IASB standards and proposes the removal of most of the differences noted in the document by 
deleting items currently required under the extant AASB standard. Some differences are to be maintained 'for the time being' or because of transitional issues in the adoption of IFRSs in Australia, but in the main ED 151 recommends the removal of virtually all differences between the two sets of standards. A careful analysis of the recommended changes serves to highlight the big flaw in adoption of IASB standards, the disclosure requirements in Australian standards were generally higher than in the relevant IFRS and the quality of information available to investors was often higher under the Australian standard. Thus, the adoption of ED 151 will significantly lower both the quantity and quality of information available to investors. Such a move contradicts the decision-usefulness objective of financial reporting and should be resisted.

There are a number of proposals in ED 151 that cause concern. However, this paper is only concerned with the proposal to allow the option to use the indirect method for the presentation of cash flow statements in AASB 107 Cash Flow Statements as a prime example of the problem.

The rest of this paper will briefly discuss the concept of quality in accounting standards then describe the historical trends in standard setting since the 1930s before examining the strategic role of accounting standards in the Australian economy. The paper then shows how the proposal to allow reporting entities to use the indirect method is incongruent with the objective of financial reporting, as the majority of Australian reporting entities are expected to adopt the less informative indirect method, due to a bias in AASB 107.

\section{Quality of Accounting Standards}

A number of practitioners and academics have argued that the quality of existing or proposed accounting rules should be assessed by whether the rules increase the quality of decision-useful information for users. For example, Jonas and Blanchet (2000) argue that accounting rules should not be designed in a way that obfuscates or that misleads users. The American Accounting Association's Financial Accounting Standards Committee (1998) argue that proposed accounting rules should only be introduced if they address a deficiency in the present accounting rules and if the rules improve the ability of users to make investing decisions. In a similar vein, the Association for Investment Management and Research (AIMR) issued guidelines by which they evaluate the quality of financial accounting standards. The top two characteristics developed are:

(1) A new standard should improve the information that is available to investment decision makers.

(2) The information that results from applying a new standard should be relevant to the investment evaluation process (Knutson et al, (1998, p171)

The AICPA has expressed similar views. The Jenkins Report (1991) makes a number of recommendations to improve the quality of general-purpose financial reports (GPFR). This report calls for improved disclosures and reporting for a range of transactions, as users surveyed in the study indicated that they did not understand information relating to a range of transactions. The inability of users to understand the accounting treatment of these transactions was seen as reason enough to recommend an improvement in the way these transactions are treated in the GPFR.

There is also some evidence that the preparers share some of the concerns expressed by these commentators. Reither (1998) reports a survey of preparers who ranked certain American 
accounting rules where FASB Statement 13, relating to operating leases, and Opinion No.16, relating to business combinations were identified as the two worst American accounting rules. Both rules were criticized for allowing the form of the transaction to prevail over the substance and for allowing similar transactions to be reported differently. It is arguable that accounting rules such as these are of low quality, as they are incongruent with the decision-usefulness objective.

\section{Background to ED 151}

On 4 March 1997 the Australian Treasurer announced that a paper on reform of the accounting standard setting process in Australia would be released as part of the Government's Corporate Law Economic Reform Program (CLERP). The paper became available in October 1997 and it contained a number of proposals including the following items of primary interest to the accounting profession:

1. The Role of Accounting Standards.

2. Harmonisation with International Standards.

3. Institutional Arrangements for Standard Setting in Australia.

These three issues raised in this paper concerned accounting and professional standards, harmonisation with international standards and Australian institutional arrangements. These three issues remain significant today in any analysis of ED151.

Since the original paper a number of changes to the standard-setting regime were put in place as a result of the CLERP Act 1999. This was followed by CLERP 9, entitled Corporate Disclosure: Strengthening the Financial Reporting Framework, which was published in September 2002. Part 6 of CLERP 9 dealt with accounting standards and confirmed a new and very tight deadline for the adoption of International Financial Reporting Standards (IFRS) by the Financial Reporting Council (FRC), as explained by the then chairman of the Australian Accounting Standards Board (AASB), (Alfredson, 2003 p3)

"Under the strategy adopted by the Financial Reporting Council (FRC) at its meeting on 28 June 2002 and publicly announced on 3 July 2002 (FRC Bulletin 2002/4), the Australian Accounting Standards Board (AASB) is obligated to work towards the full implementation of international accounting standards now known as International Financial Reporting Standards (IFRS), in Australia in respect of financial years starting on or after 1 January 2005."

The deadline for adoption and the policy of adoption of International standards was criticised on two main grounds. Firstly, that the 2005 deadline was too short and secondly, that Australian Accounting Standards are of high quality and, arguably, better in many regards than many of the IFRS that will take their place. International accounting standards began as very general statements arising from political compromise between those countries who dominated the International Accounting Standards Committee (IASC), as it was then known, and were often regarded as reflecting the lowest common denominator which tends to arise from political compromise.

IASB standards are now regarded as reasonable quality standards because of a process of improvement which has been undertaken over recent years, though many of the old IAS 
standards remain in place and these are in need of improvement. Unfortunately, in a number of areas they are still more permissive than Australian standards and their adoption in 2005 has required significant adjustment to accounting practice in Australia.

There were 37 Australian accounting standards at the time of implementation and 34 of these were changed significantly to cope with the adoption of IASB standards. The process of harmonization that was commenced in 2005 was only the first step in the process of altering (and often reducing the quality of) Australian financial reporting standards. The hasty adoption of international standards was unfortunate because the resources of the IASB have not been sufficient for them to completely upgrade the old IAS standards and we have been left with a mix of IFRS standards which appear to be of reasonable quality and old IAS standards which are in need of review and updating.

\section{A Short History of Standard Setting}

The trend during the last century has been towards the regulation of disclosure practices of reporting entities. Corporate legislation has become more prescriptive and a range of institutions have developed around the world to direct disclosure practices and to administer companies and securities legislation. These institutions have generally acted in ways that are congruent with the decision-usefulness objective by acting to reduce the scope for manipulation of general-purpose financial accounting reports.

The Securities and Exchange Commission (SEC) was established by the US Congress in 1934 to administer various federal laws dealing with the trading of securities shortly after the American Institute of Certified Public Accountants (AICPA) began a co-operative effort with the New York Stock Exchange (NYSE) aimed at establishing standards of accounting practice to be followed by corporations. This collaboration produced a recommendation that, within very broad limits, every corporation should be free to choose its own methods of accounting so long as the methods used were disclosed and applied consistently from year to year. However, in April 1938 the SEC required the profession to establish a standard setting body under threat of the SEC developing its own accounting principles (Accounting Series Release (ASR) No. 4). Consequently, the AICPA empowered its Committee on Accounting Procedures (CAP) to issue a range of pronouncements on accounting practice and principles.

The AICPA led accounting professional bodies in producing accounting standards, with other professional bodies around the world soon moving to assume the standard setting role. In Australia in 1944 the Institute of Chartered Accountants in Australia (ICAA) established a 'technical committee' which began to issue a series of 'recommended accounting principles' to its members.

Regulatory bodies like the SEC were much slower to develop in Australia. The mining boom and corporate failures of the early 1960s led the Senate Select Committee on Securities and Exchange to recommend the establishment of a regulatory agency to protect the investing public. But it was only in 1978 that a national co-operative scheme of regulation of the securities industry began which led to the establishment of the National Companies and Securities Commission (NCSC) in 1979. At the same time the professional bodies started developing accounting standards and refining their principles, in order to improve the quality of decision- 
useful information for users. Eventually, the accounting standards developed by the professional bodies were given force of law through the Corporation Law of 1991.

A similar trend emerged in the United Kingdom where the accountancy professional bodies started developing accounting standards in 1970 with the formation of the Accounting Standards Steering Committee (ASSC), now known as the Accounting Standards Board. It is interesting to note the terms of reference of the ASSC included:

... to advance accounting standards and to narrow the areas of difference and variety in accounting practice.

This discussion shows how standard setters have traditionally acted to improve the quality of GPFR. It seems that the present members of the AASB have rejected or at least failed to adopt this approach, despite the fact it has been used for a number of decades by countries with the largest capital markets and continues to be used by those countries.

\section{The Strategic Role of Accounting Standards and the Role of the AASB in Developing Standards}

Unfortunately, or perhaps fortunately, debates about accounting standards affect more than accountants and financial report users. Governments and other stakeholders have long recognised that accounting standards can have a profound effect on issues sensitive to them ${ }^{1}$. The strategic role of accounting standards in the Australian economy is recognized in recent legislation which requires accounting standards to achieve three outcomes ("Australian Securities and Investments Commission Act," 2001 Section 224). These outcomes are:

* to facilitate the development of accounting standards that require the provision of financial information that: allows users to make and evaluate decisions about allocating scarce resources; assists directors to discharge their obligations in regard to financial reporting; is relevant to assessing performance; financial position; financing and investment; is relevant and reliable; facilitates comparability; and is readily understandable;

* to facilitate the Australian economy by: reducing the cost of capital; enabling Australian entities to compete effectively overseas; and having accounting standards that are clearly stated and easy to understand; and

* to maintain investor confidence in the Australian economy (including its capital markets).

Therefore it would be expected that any proposal to modify extant accounting standards used in Australia would need to be debated within the prism of the objective of financial accounting and the strategic role of those standards.. As will be shown below, ED 151 seems to have ignored all these considerations.

\footnotetext{
${ }^{1}$ There are many examples of other stakeholders affecting accounting debates. Recent examples include the lobbying on the G4 + 1 proposal to modify accounting for leases (Barents Report, 1998; ABN AMRO, 2000; Australian Institute of Company Directors, 2000; British Bankers' Association, 2000) and the lobbying by the IT industry to prevent the expensing of options(Software and Information Industry Association, 2003).
} 
For some time there has been a public understanding of certain shortcomings with International Accounting Standards. Corporate Law Economic Reform Program (CLERP) Paper No. 1 identifies certain problems with International Accounting Standards as centered around qualitative issues such as

"... the use of too many options in the preparation of financial reports;

... insufficient explanatory material and guidance on use; and ... incomplete(ness) - there are gaps in the standards." (s5.3)

It further notes that "... the form and content of Australian accounting standards are broadly consistent with those existing in other countries with sophisticated capital markets" (s4.2). It is suggested, however, that "... there may be scope for better targeting and design of particular standards" (s4.2). This is hardly a compelling argument for mass replacement of Australian accounting standards with existing international standards. This is particularly so for proposals that seek to reduce the quality or quantity of information available to users.

Harmonisation with international standards has always been a feature of Australia's accounting standards, which have always been compatible with international standards. However, ED 151 seems based on the idea that uniformity (at any cost), rather than harmonisation is desired. Any attempt to impose uniformity upon a diverse range of national jurisdictions with different cultural, legal and taxation traditions is unlikely to succeed, as has been seen in America's response to the introduction of international accounting standards. The Financial Accounting Standards Board (FASB) in the USA has promulgated far more standards than any other country and it may be very difficult or impossible to get the USA to follow IASB standards without some significant changes to the extant IASB standards.

It is obvious that Australia does not have the economic power to adopt the American response to the introduction of IASB standards. However, the AASB should have adopted a similar point of view to that of the FASB and used its influence and resources to agitate for the development of higher quality accounting rules, instead of meekly adopting the lowest common denominator in order to achieve standardization. As argued above, standard setters should aim to reduce diversity, improve disclosure and ensure consistent application of principles over time, with an overall aim to produce decision-useful information

\section{General Problems with ED 151}

On the face of it ED 151 appears likely to reduce the quality and quantity of information provided to the users of financial statements as it proposes the removal of a significant number of disclosure requirements which are currently peculiar to AASB standards. It also proposes to allow some alternative treatments in particular areas where Australian standards have not allowed alternatives in the past, thus moving away from the traditional approach of standard setting which has tried to reduce the range of different treatments available for the presentation of information. Perhaps the most significant of these is the proposal to allow cash flow statements to be prepared using either the direct or the indirect method. Most countries have allowed the use of either method for some time, with the result that the indirect method has come to dominate disclosures overseas. This proposal is an issue of some concern, as it is likely to lead to a lower quality accounting standard and reduced quality disclosures of information for investors. 


\section{The Problem with ED 151's approach to the Statement of Cash Flows}

The Exposure Draft proposes to allow reporting entities the option of using the direct or the indirect method for presenting cash flows from operations. The Board's proposal to open the door to the indirect method is surprising as it is well established in the literature 'that the indirect method greatly undermines and diminishes the relevance and mission of the cash flow statement' (Jones et al., 1995, p115).

This proposal will lead to a lower quality accounting standard. There is considerable evidence that the indirect method is widely adopted by companies that are allowed this option. For example, Clinch et al., (2000) refer to a survey conducted by the AICPA in 1992 that found $97.5 \%$ of companies surveyed used the indirect method in the USA. Broome (2004) reports similar figures. There is no reason to believe that Australian reporting entities would behave differently to American companies and so we would expect to see a substantial move to this format even though there is no reason to do so based on cost of the presentation. The literature is full of studies of opportunistic behaviour by management which lowers the quality of disclosures and allows the manipulation of accounting accruals and the indirect method of presenting cash flow statements supports this type of opportunistic behaviour by management (for example Dechow and Dichev (2002), Francis et al (2005)). Thus, the changes proposed will mean that users will lose easily understandable information that does not contradict IASB standards, and that investors will be more exposed to opportunistic behaviour by management.

The high rate of use of the indirect method by American companies is particularly interesting, given that the FASB recommends the direct method over the indirect method, presumably because it believes this method provides better quality information. It is then surprising to see that the majority of American companies seem to have ignored the FASB's recommendation.

Broome (2004) suggests the direct method can be more expensive for companies to use, compared to the indirect method because of the presentation requirements of the US standard . The American standard on cash flows, SFAS 95, and the IASB standard IAS 7 have similar biases which favour the indirect method, as both standards require companies to prepare the indirect method as a reconciliation in the notes if they use the direct method. However, if companies choose to use the indirect method in the statement of cash-flows, they are not required to present the direct method in the notes. This situation greatly increases the attractiveness of the indirect method, as it reduces the amount of work to be carried out by the preparers.

Unfortunately, there does not appear to be much empirical research into the quality and information content of the direct method compared to the indirect method. We suspect this is because companies within a country are either forced to use the direct method (Australia and New Zealand) or predominantly use the indirect method when given the option. What research there is tends to support the direct method over the indirect method. There is some evidence from a number of studies which indicate that a range of financial statement users prefer the direct method over the indirect method (Clinch et al., 2000). Jones et al. (1995)shows that pressure from the ASX, the ultimate representative user group, was responsible for the adoption of the Statement of Cash Flows in Australia. They also claim a wide range of user groups in Australia preferred the direct method over the indirect method when presenting cash flows from operations, hence the mandated use of this form of presentation in AASB 1026. 
Frino and Jones (2005) found that the introduction of AASB 1026, the former Australian standard, was associated with a reduction in the bid-ask spread for ASX listed Australian companies that had not previously presented cash-flow information. This reduction was more pronounced for those companies with a low correlation between reported cash flows from operations and estimated cash flows from operations ${ }^{2}$. This indicates something of the importance of information contained in cash flow statements at the moment as many studies have found that there is a low correlation between short-term operating cash flows and profits and that intertemporal differences between these two measures can convey useful information about firm solvency and the capacity of shareholders to make abnormal short-term returns from this difference (for example Bowen et al,(1986), Andrew et al (1988)).

A major concern with the introduction of the indirect method is the extra burden placed on users to estimate the elements of operating cash flows, such as cash collected from customers and cash paid to suppliers and employees. Hribar and Collins (2002) show that estimates of cash flows from operations are likely to be substantially different to reported figures when companies engage in a range of reasonably common transactions such as undertaking mergers and acquisitions, discontinuing operations and dealing with foreign currency translations.

Other authors argue that the indirect method is difficult to understand as it 'requires a myriad of special adjustments to income' (Mello-E-Souza, 2006 p1). Academics teaching accounting students have some understanding of the complexity of these adjustments and especially the need to remove short-term accruals from the published profit figure in estimating cash from operations reported under the indirect method. We very much doubt that users, especially retail investors, but also some professional analysts, are able to exactly calculate the cash collected from customers, the borrowing costs paid and the amount paid to suppliers and employees using the information in the general purpose financial reports where the indirect method is used. Frino and Jones (2005) cite previous studies which support this concern.

Of course, it is possible to derive an approximation of the elements which make up the cash flow from operations. These elements include cash collected from customers, cash payments to suppliers and employees etc. However, this raises the obvious question of why we would adopt an accounting standard that forces users to undertake complex analysis in order to produce figures that are an approximation of the underlying position. We suggest that critics of this view attempt to derive the:

- amount of cash collected from customers,

- borrowing costs paid, and

- $\quad$ cash paid to suppliers and employees

\footnotetext{
${ }^{2}$ Before AASB 1026 was introduced, reporting entities had to produce a Statement of Sources and Applications of Funds. This statement did not concern itself with cash flows and was discarded in the aftermath of the spectacular collapses of the early 1990s, when many users and other commentators demanded information related to movements of cash, rather than the more nebulous concept of funds. Users previously had to try to estimate the cash flows from operations. This was often done by making adjustments to the reported figures in the balance sheet and the income statement. There was often a substantial difference between the reported figure after the introduction of AASB 1026 and the estimated figure.
} 
for reporting entities with fairly simple operations, such as Woolworths or Coles, then try it for entities that are slightly more complex, such as Macquarie Airports etc. It is not to say the analysis can't be done, but to illustrate how much more analysis users need to undertake in order to obtain information that currently exists and will be lost, if the majority of reporting entities in Australia adopt the indirect method of reporting cash flow from operations. Extrapolating from Frino and Jones (2005), we suggest that a move from the direct to the indirect method will increase information asymmetry in the market, as many users are unable or unwilling to expend the time and effort to obtain the information that is currently presented under the direct method. Frino and Jones (2005) suggest an increase in information asymmetry will lead to an increase in the bid-ask spread. This increase in uncertainty will likely increase investment risk and can be expected to lead to higher costs of capital.

Under these circumstances it appears likely that the Board's objective of a reduced cost of capital will not be met.

It is hard to see how the introduction of the indirect method is going to reduce the required rate of return (the cost of capital for Australian companies) demanded by overseas investors. These investors are presumably used to dealing with the indirect method for calculating cash flows from operations. Possibly the Board is concerned they will be put off by the direct method of calculating cash flows from operations. However, the indirect method format is currently available to those investors as a note to the statement of cash flows, so replacement of the direct method is not going to give these investors any information they don't already have. However, adoption of the indirect method will disadvantage Australian investors, who currently have access to both the direct and indirect formats for presenting the cash flow from operations. These investors can be expected to demand a higher rate of return, if only because of the increase in uncertainty and information asymmetry that will arise when Australian reporting entities move to the indirect method.

At risk of labouring the point, reductions in the cost of capital are only going to occur if the market believes the new information set is better than the previous one and there is little doubt that the current requirement of AASB 1026 to report the two formats is superior to the international standard which normally requires only one, the less informative indirect format.

\section{Conclusion}

The thrust of ED151 is to remove the last aspects of diversity between Australian Accounting Standards and International Financial Reporting Standards. On the face of it this would seem to be reasonable enough so long as there are significant areas of difference between the two sets of standards and the international standards are superior or of equivalent quality. Unfortunately, neither of these caveats appears to be realized, as in all cases ED151 seems to be removing some aspect of disclosure from the extant Australian standard and the consequence of this will likely be a reduction in the quality and quantity of information disclosed under the new Australian standard. Such an outcome is not desirable unless there are some other benefits of great moment which will arise from the change, but the suggested benefits of standardization appear to be intangible and not quantified anywhere, though the costs of the new proposals are likely to be high for preparers of financial statements, who must again adjust to another new regime, and to the users of financial statements, who will lose access to information which is currently available. 


\section{REFERENCES}

ABN AMRO. (2000). Leases: Implementation of a new approach (G4+1 position paper).Unpublished manuscript, Brussels.

Alfredson, K. (2003). Pathway to 2005 IASB Standards. Australian Accounting Review, No. 29.

American Accounting Association Financial Accounting Standards Committee. (1998). Criteria for assessing the quality of an accounting standard. Accounting Horizons, 12(2), 161-162.

Andrew, B. H., Austin, L. and Chew, A,. (1988). A Study of the Relationship Between Three Business Flows: Some Evidence from Singapore. International Journal of Accounting Education and Research, Vol 23(No. 2).

Australian Accounting standards Board. (1991). AASB 1026 Cash Flow Statements.

Australian Accounting Standards Board. (2006). Exposure Draft 151: Australian Additions to, and Deletions from, IFRSs. Melbourne.

Australian Institute of Company Directors. (2000). AICD submission on G4+1 Position Paper - Leases. Retrieved 1 March, 2006, from

http://www.companydirectors.com.au/Policy/Submissions/2000/AICD+Submission+on+G41+Position+Pap er+-+Leases.htm

Australian Securities and Investments Commission Act, (2001).

Barents Report. (1998). Preliminay investigation of potential impacts of changing to an asset/liability framework in accounting for leases. Arlington: Association for Equipment Leasing and Finance.

Bowen, R. M., Burgstahler, D, and Daley, L.A,. (1986). Evidence on the Relationships Between Earnings and Various Measures of Cash Flow. The Accounting Review(October).

British Bankers' Association. (2000). G4+1 discussion paper: Leases: Implementation of a new approach: Comments by the British Bankers' Association.Unpublished manuscript, London.

Broome, O. W. (2004). Statement of Cash Flows: Time for Change. Financial Analysts Journal(March/April).

Clinch, G. J., Sidhu, B. K., \& Sin, S. (2000). The Usefulness of Direct and Indirect Cash Flow Disclosures. Retrieved February 15, 2007, from http://ssrn.com/paper=251957

Dechow, P., and I. Dichev,. (2002). The quality of accruals and earnings: The role of accrual estimation errors. The Accounting Review, 77 (Supplement), 35-59.

FASB. (1987). Statement of Financial Accounting Standards No. 95: Statement of Cash Flows.

Francis, J., LaFond, R., Olsson, P., \& Schipper, K,. (2005). The Market Pricing of Accruals Quality. Journal of Accounting and Economics, 39.

Frino, A., \& Jones, A. (2005). The Impact of Mandated Cash Flow Disclosure on Bid-Ask Spreads. Journal of Business Finance and Accounting, 32(7)\&(8).

Hribar, P., \& Collins, D. (2002). Errors in Estimating Accruals: Implications for Empirical Research. Journal of Accounting Research, 40(No. 1).

IASB. (1992). IAS 7 Cash Flow Statements.

Jenkins, E. L. (1991). Meeting the Information Needs of Investors and Creditors: Comprehensive Report of the Special Committee on Financial Reporting. (The Jenkin's Report): American Institute of Certified Public Accountants.

Jonas, G. J., \& Blanchet, J. (2000). Assessing quality of financial reporting. Accounting Horizons, 14(3), $353-363$.

Jones, S., Romano, C., \& Smyrnios, K. (1995). An Evaluation of the Decision Usefulness of Cash Flow Statements by Australian Reporting Entities. Accounting and Business Research, 25(No. 98).

Knutson, P. H., \& Napolitano, G. N. (1998). Criteria employed by the AIMR Financial Accounting Policy Committee in evaluating financial accounting standards. Accounting Horizons, 12(2), 170-176.

Mello-E-Souza, C. A. (2006). Taking the Mystery out of the Cash Flow Statement: A Simplified Implementation of the Indirect Method 10.2139/ssrn.424201. SSRN eLibrary.

Reither, C. L. (1998). Commentary: What are the best and worst accounting standards? Accounting Horizons, 12(2), 283-292.

Software and Information Industry Association. (2003). Re: Invitation to comment on accounting for stock options. Retrieved March 1, 2007, from http://www.siia.net/govt/docs/pub/tax_letter_013003.pdf

The Treasury. (1997). CLERP Paper No.1: Accounting Standards. Commonwealth of Australia Government.

The Treasury. (2002). CLERP Paper No. 9: Proposals for Reform - Corporate Disclosure. Commonwealth of Australia Government. 